\title{
Development and Validation of Performance Appraisal Scale (PAS-HSSTS) for Higher
}

\author{
Secondary School Teachers \\ * Muhammad Nadeem, Principal Officer \\ ** Dr. Seema Arif, Associate Professor \\ *** Dr. Muhammad Zaheer Asghar, Assistant Professor
}

\begin{abstract}
A study was conducted to develop the research instrument for evaluating the Performance Appraisal System (PAS) at public higher secondary schools in Punjab. Data were collected from the three divisions total $(N=900)$ male and female teachers of public schools using a multi-stage sampling technique. The questionnaire was founded on the factors elaborated in the Performance Evaluation Report (PER), National Professional Standards (NPS) for teachers. This scale is extended to evaluate the satisfaction of the teachers with the performance appraisal process. The factors taken from PER are classroom management, quality of teaching, motivation, teamwork, and punctuality, whereas Awareness, Satisfaction with PAS, Dissatisfaction with PAS, and Need for Improvement were added by the researchers to evaluate the PAS process. Performance Appraisal Scale for higher secondary school teachers (PAS-HSSTS) contained 57 items. The experts' opinion was sought to check for content validity, and a pilot study was performed with 300 teachers from public higher secondary schools. The reliability coefficient (Cronbach alpha) of the instrument was .866 for the pilot and .883 for final data. Structure Equation Modelling (SEM) was used for the validation of the instrument (PAS-HSSTS) using Confirmatory Factor Analysis (CFA). The factor loadings of all items used in the scale were well above the threshold value 0.35. The SEM results indicated that Fit indices for PAS resulted in an acceptable model fit.
\end{abstract}

Keywords: Performance Appraisal, SEM Analysis, Awareness, Satisfaction with PAS, Introduction

Dissatisfaction with PAS, Improvement Needs of PAS.

Performance Appraisal System (PAS) is a regular process that evaluates the employees' tangible performance relevant to the required criteria and provides feedback to them (Tong \& Arvey, 2015). Firestone (2014) argued that feedback had been an under-discussed segment of teacher appraisal, critical for motivation, therefore. PAS is a phenomenon in which a school head or manager analyses teachers' job performance. The main goal of all appraisals is to evaluate and analyze whether a teacher has the skills and qualities needed for effectively doing his/her job. There is a pre-decided criterion that school principals use to judge teachers' performance (Warokka, Gallato, Thamendren, \& Moorthy, 2012; Nadeem, Arif \& Zaheer, 2019).

PAS is a high stake evaluation instrument, in which quantitative scores are allotted on the required level of the employee's job performance. It is conducted in an organized manner, which is when the supervisor or management measures/adjust the salary of the employees according to the target met by them and objectives achieved by them (Reddy et al., 2018). Moreover, the supervisor also examines the dynamics behind the performances of staff members and guides the employees to achieve better and enhanced performance in the future. These days, most of the institutes conduct performance appraisal once a year (Ahmad \& Azman, 2014), so is the case with Pakistani Public Higher Secondary Schools. Accurate evaluation of performance amplifies workers' productivity and motivates them to work more sincerely (Islami, Mulolli, \& Mustafa, 2018).

\footnotetext{
* Mines and Minerals Department Mianwali, Punjab, Pakistan Email: mnadeem439@gmail.com

** University of Management and Technology Lahore Punjab, Pakistan Email: seema.arif@umt.edu.pk

*** University of Management and Technology Lahore, Punjab, Pakistan Email: chancellor.zaheer@ gmail.com
} 
The study concludes that a performance appraisal system is beneficial in reaching several objectives, especially in improving decision making processes and setting future goals for the organization. It allows employees to correctly judge their strengths and weaknesses, work efficiency, and work towards improvement (Edoziem \& Nwideeduh, 2020). Therefore, it is recommended that school principals should carefully envisage the performance appraisal that how it would give the best results; to achieve this objective, all performance appraisals should be result-oriented and be targeted at teacher's improvement. It must function to provide the right information at the right time for teachers to save resources from wastage while teaching them to make the right decisions in the nick of time. These empirical findings corroborated the findings obtained by some researchers (Iqbal, 2013; Warokka et al., 2012).

\section{Literature Review}

The performance appraisal is viewed as an opportunity through which the management can decide whom to give reward or appreciation for their outstanding performance (Almeida \& Fernando, 2017). In simpler words, the concept of performance appraisal can be understood as the systematic evaluation of the performance of staff according to their job responsibilities to look for their developmental potencies. There are various methods of calculating an employee's performance. One of them is the 'Management by Objectives' method. It includes comparing set goals and standards for a worker with the actual contribution and productivity of an employee. Another way is '360 Degree' in this method; an employee is judged and evaluated by everyone, from his manager to co-workers, friends, and even consumers and suppliers. It is further stated that self-appraisal takes place with the help of joint discussion with superior, and then decisions are taken by the department leader relative to his promotion and pay hike. The report related to job performance is openly given to the employee.

Teacher evaluation is an element of prime importance to improve teacher efficiency (Howard $\&$ McColskey, 2001). For a long time, the frequently questionable device of observation has been the only way utilized in forming meaningful choices for the teachers in their future careers (Marx, 2007; Peterson, 2004). In the teacher evaluation process, an attempt to minimize subjectivity, and with the widely accessible data, material availability has prompted an ongoing enhancement (Hamilton, Schwartz, Stecher, \& Steele, 2013). Now PAS has been changed to meet the required standards. In recent times, the rating has a limited value, which starts with appreciation. The present system of performance appraisal is much broader and a preferred self-appraisal system (Edoziem \& Nwideeduh, 2020; Nadeem, Arif, \& Naeem, 2020). The principal is the one who takes instructions from the educational administrators for the policy implementation in the conduction of PAS.

Expectancy theory is evident that one's motivation depends upon an individual's quest for achieving some goals. Such kind of motivation is needed for the employees through whom they made it possible to comprehend the connectivity between effort, performance, and rewards. Furthermore, it is considered that performance is a critical element of the expectancy effort. It shows the close connectivity between effort and performance. So, in this regard, it is expected that such a kind of struggle will broaden away for excellent efficiency.

Furthermore, the subjected efficiency will end up with the desired goals. The researcher selected the conceptual framework factors from the Performance Evaluation Report (PER), National Professional Standards (NPS) for teachers, and my already established tool Performance Appraisal Scale for Secondary School Teachers (PAS-SSTs) (Farooqi, Akhtar, \& Nadeem, 2013; Nadeem, Farooqi, Shehzad, \& Ahmad, 2014). According to NPS, the behavior of teachers to be observed as classroom management, quality teaching, punctuality, motivation, and teamwork and in the PER targets are set by the managers for the teachers to achieve their educational goals based on the above actions (Stufflebeam, 2003).

In this study, considerable literature has been reviewed that manifests different concepts connected with the appraisal system. The researcher has reviewed different themes associated with the execution, processes, and models of teacher appraisal. According to Akin, Yildirim, and Goodwin (2016), education is defined concerning the quality of teaching, and it depends on the high performance of teachers in the respective subject. An organization depends upon performance appraisal just to appreciate and encourage employees to ensure that organization is on its way to progress. The study evaluates the procedures and assessment of teachers' performance in terms of providing quality education to students. 
The researcher developed PAS-HSSTs for the evaluation of teachers' performance. The study at hand contains ten factors of teaching which describe constructive influence on the teacher's performance. These factors are awareness, classroom management, quality teaching, motivation, teamwork, punctuality, management role, satisfaction, dissatisfaction, and need for improvement. These factors are described below:

\section{Awareness}

In the context of teachers' performance appraisal, the management and the head of the school is required to guide teachers about the basics of PAS and its implementation process (Kanto, Ahmad, Talib, \& Tiro, 2014). It allows the teachers to understand how the appraisal system will evaluate their performance (Firestone, 2014). Thus, it can be said that with the help of the appraisal system, the teachers identify what performance is required from them, which allows them to maintain their teaching standards throughout the appraisal process. The performance appraisal model puts a yearly appraisal system forwards through this very system. All the staff members are asked to fill up an annual work plan form regarding the progress of the given goals. Expected outcomes of the work are always a great source of motivation and efficiency of an employee in an annual appraisal system.

\section{Actions to be evaluated by PAS}

Furthermore, actions are evaluated based on awareness of the PAS process.

Classroom management: Classroom management is a significant impact of the work of any teacher includes the proper management of the classroom and skills to make students disciplined so that they behave in an appropriate manner (Kwok, 2017). DeMoraes (2019) highlighted that it is also essential to evaluate how a teacher demonstrates evenness and equality. The appraisal action of classroom management also entails how a teacher is involved in arranging effective instruction for students in the classroom. It is closely related to matters of inspiration and self-control, which is not only maintaining direction but also improving the learning of the students.

Quality Teaching: Performance appraisal action entails the identification of teaching quality, and it is resourceful in enhancing the quality of teaching (Simmons, 2003). It is the most critical school variable encouraging student success (Perlaza \& Tardif, 2016). Mayer (2014), as cited in the research of Elliott (2015), that standards that are formulated in schools regarding required teaching quality should be able to raise reliability and responsibility among teachers and they should also act as the basis for the review of performance at the end of each cycle of the appraisal.

Motivation: When performance is evaluated and teachers who stand out as extraordinary receive reward, it increases their motivation. Hence, PAS is used by modern organizations as an instrument to enhance employee's motivation and improve communication skills (Brefo-Manuh, Anlesinya, Odoi, Owusu, 2016).

Teamwork and Punctuality: Teamwork is essential for teachers as they collectively teach the students, and if they do not coordinate well enough, students will not receive a coherent education (Ronfeldt, Farmer, McQueen, \& Grissom, 2015). The punctuality of the teacher, linked with the disciplinary aspect, is one of the leading indicators of performance in PAS. Thus, being punctual is one of the foundations of discipline that teachers are required to exhibit to preach it (Gelder, 2005).

\section{Management Role}

Management support plays a crucial role in the PAS process, especially in the guidance and supervision of teachers. The role of the principal is vital in the implementation of teachers' appraisal and enhancing their performance (Taut \& Sun, 2014). Therefore, administration in schools is responsible for carrying out development, carry on a conversation with teachers, and motivate them towards high performance.

\section{Outcomes of PAS}

Satisfaction / Dissatisfaction: Performance appraisal is the degree in which the staff of an organization rating the performance of employees, which imitates the behavior that is required to contribute in the organization (deNisi \& Murphy, 2017). PAS proves to be the required tool that allows them to obtain feedback and review their performance at the workplace (Buckingham \& Goodall, 2015). In the context of schools, implement a performance evaluation system and receive satisfying results in terms of increasing the competencies of their teachers (Ballou \& Springer, 2015; Ali, Dahie, \& Ali, 2016; Finster \& Milanowski, 2018). Sometimes, the staff in an organization feels dissatisfied with PAS due to the reason that the implementation of PAS includes partiality, which demotivates the skilled staff. Thus, the overall results of the appraisal are also presented unjustly. Due 
to this, the organizations are unable to gain actual benefits of the appraisal process. Therefore, it is assumed that if teachers are satisfied with the PAS, then not only will they be committed to PAS but involve in the process enthusiastically, and they will concern with the improvement of the process as well. If teachers are dissatisfied, then they will show a lack of concern \& commitment to PAS.

Need for Improvement: The purpose of PAS is to bring overall improvement in the performance of employees. For bringing continuous improvement in PAS, it is needed to retain some aspects of the system, and based on feedback, training must be provided to the teachers (Campatelli, Citti, \& Meneghin, 2011). The following figure shows the factors influencing the PAS;

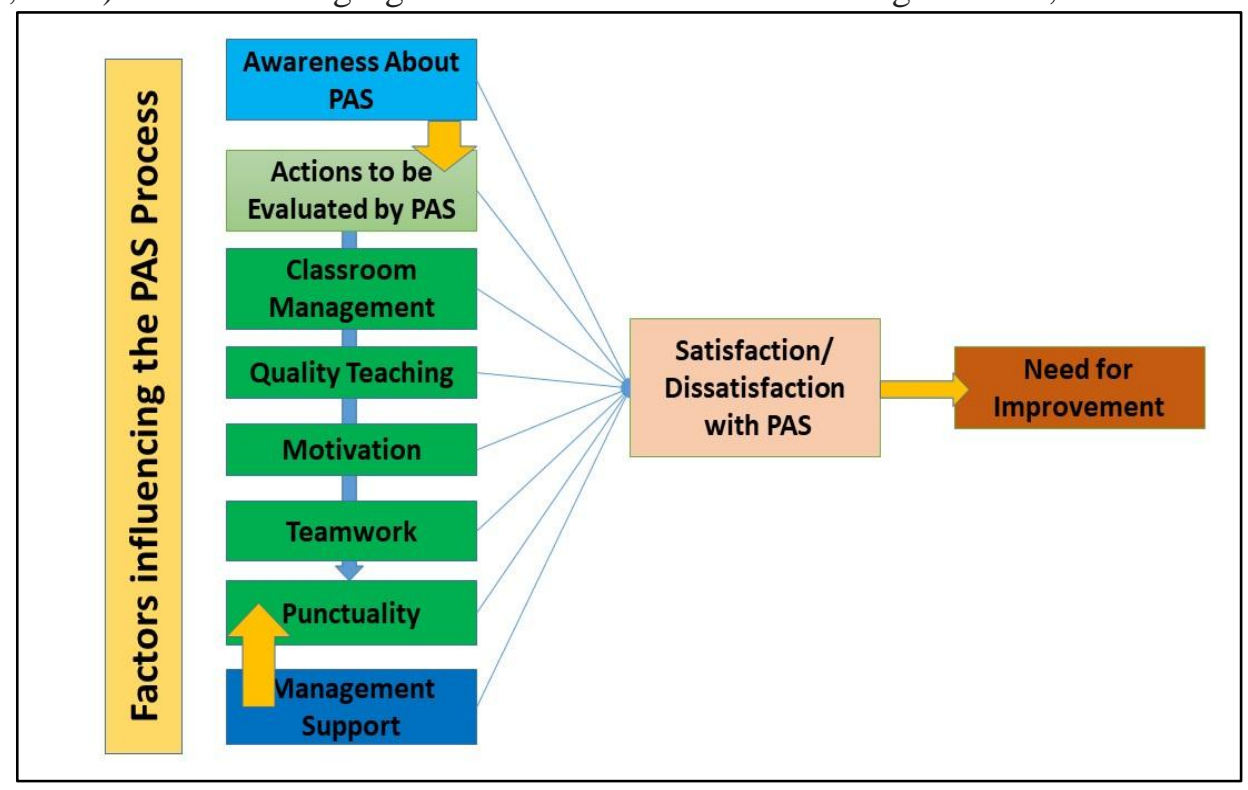

\section{Instrumentation}

Figure 1 The PAS process of the study

The instrument was self-developed to make it compatible with the local context. The items constructed were based on the guided review of literature and teachers' comments collected in a focus group with teachers, to whom the results were to be generalized. All items were close-ended developed on a Five-point Likert Scale. The questionnaire was divided into two parts. Part A collected demographic details of the participants and the second comprised items on the scale to be developed.

\section{Validity and Reliability of the Instrument}

The questionnaire was reviewed, and pilot tested for face and content validity. The items for the questionnaire were peer-reviewed by some senior practitioners (schoolteachers) for face and content validity. Moreover, the sequence of items, readability, comprehension level appropriate use of language, and length of the questionnaire were considered for revision. The aim of confirming face validity was to sequence the items, ensure the appropriate use of language, and evaluate the length of the questionnaire. The questionnaire thus constructed was further reviewed by selected university professors for content validity; 5 professors examined the questionnaire for its content, two professors examined the questionnaire for appropriate use of language, and three professors including a professor of statistics validated the items for further use of statistical measures such as factor analysis. They vetted the research tool, and some commendable corrections were made. A 70-item questionnaire was thus generated.

\section{Pilot Testing}

Pilot testing of the generated questionnaire was performed with 300 higher secondary school teachers of the Sahiwal division. 0.832 was the calculated value for Cronbach Alpha, a well-reputed measure of reliability. The pilot data was well factorized as well, giving a clean signal for further data collection. Thirteen items were found redundant and were excluded from the questionnaire. The researchers removed the data of all respondents who had ticked on the same category on all items, and those who have completed fewer than the $80 \%$ of total items on the questionnaire. This way, the researchers retained the data of 900 respondents with a $1.3 \%$ rate of incomplete responses. The missing responses were completed by a random number as suggested by McKnight, McKnight, Sidani, \& Figueredo (2007). 


\section{The Final Questionnaire}

The final questionnaire for developing a scale for Performance Appraisal Scale for Higher Secondary School Teachers (PAS-HSSTs) consisted of 57 items comprising two parts. Part A collected demographic information. Part B comprised the factors of the study; 6 items about awareness regarding performance appraisal and 11 items about classroom management were included. 6 items measured the quality of teaching and another six motivation. Teamwork and punctuality were assessed on an eight-item scale. 6 statements evaluated satisfaction with PAS; five items each for management support and dissatisfaction with PAS and four items need for improvement.

\section{Data Collection}

The total data were collected from 900 teachers from three divisions (Lahore, Sargodha, and Multan). The researcher used the multi-stage sampling technique in this study. Data was collected personally or through experienced associates trained to explain and clarify if any misunderstanding occurred. Final data were analyzed using SPSS 21, and the calculated value of reliability (Cronbach's alpha) was 0.883 . The pilot test's alpha value of 0.862 and 0.883 of the final data suggested that further analysis could be pursued with the data, as marked by McKim (2017).

\section{Results}

Confirmatory factor analysis was applied to the questionnaire items using varimax rotated principal axis factoring (Kaiser, 1974). The use of confirmatory factor analysis assured that items selected for the final analysis were valid, that is they measured what the researchers intended to measure (Fish, Gefen, Kaczetow, Winograd, \& Futtersak-Goldberg, 2016). Varimax rotation helped in simplification of data; the value of factor loadings, thus extracted, was greater than 5 much above the recommended value of <3 (Hu \& Bentler, 1999). The analyses resulted in ten factors (subscales) with high factor loadings. The following are the details:

\section{Factor Structure of the Research Questionnaire \\ Table 1}

Factor Wise Items of PAS

\begin{tabular}{cllll}
\hline No. & Factors & Items & M & SD \\
\hline 1 & Awareness of PAS & $1-6$ & 3.8859 & .61428 \\
2 & Classroom Management & $7-17$ & 4.0202 & .35496 \\
3 & Quality of Teaching & $18-23$ & 4.3541 & .38520 \\
4 & Motivation & $24-29$ & 4.3306 & .36682 \\
5 & Teamwork & $30-33$ & 4.2942 & .40770 \\
6 & Punctuality & $34-37$ & 4.2061 & .51630 \\
7 & Satisfaction with PAS & $38-43$ & 3.1339 & .39015 \\
8 & Management Support & $44-48$ & 3.7969 & .64395 \\
9 & Dissatisfaction with PAS & $49-53$ & 4.2642 & .46275 \\
10 & Need for Improvement & $54-57$ & 2.2058 & .82100 \\
\hline
\end{tabular}

\section{Details of Confirmatory Factor Analysis}

First, the reliability of the questionnaire was calculated and found to be 0.883 , precisely. Further analysis affirmed the factorability of data into 10 factors with a value of 0.782 for Kaiser-MeyerOlkin (KMO) measure of sampling adequacy, which was more than 0.6 (Kaiser, 1974). The ten extracted factors are explained in detail below:

Factor no1: The first factor identified was 'awareness of performance appraisal.' The Factorability of the 6 items was examined; the factor loadings were all above 0.5 showing strong awareness of PAS, and the alpha score was .789.

\section{Table 2}

\section{Confirmatory Factor Analysis and Reliability Analyses (Awareness of Staff Appraisal)}

\begin{tabular}{clll}
\hline No. & Statements & $\begin{array}{l}\text { Factor } \\
\text { Loading }\end{array}$ & Alpha \\
\hline 1 & Teacher appraisal as part of an effective system & .738 & .789 \\
2 & The teaching staff had to undergo the appraisal. & .762 \\
3 & Teachers must take the appraisal process seriously & .746 \\
4 & The results of PAS can critically effect on career & .800 \\
5 & principals \& management appraise performance & .709 \\
6 & Training \& professional development is suggested & .802 \\
\hline
\end{tabular}


Factor no2: The second factor identified was 'classroom management.' The Factorability of the 11 items was examined; the alpha score was .723. The factor loadings were all above 0.5 , which shows a strong relationship with classroom management.

Table 3

Confirmatory Factor Analysis and Reliability Analysis (Classroom Management)

\begin{tabular}{clll}
\hline No. & Statements & $\begin{array}{l}\text { Factor } \\
\text { Loading }\end{array}$ & Alpha \\
\hline 7 & learning about the competencies of students of my class & .720 & .723 \\
8 & Setting appropriate tasks according to the students' grade level. & .775 & \\
9 & Using rewards as a tool to maintain discipline. & .590 & \\
10 & Managing discipline effectively in the classroom. & .628 & \\
11 & Using peer influence to manage my classroom. & .687 & \\
12 & Making decisions according to the needs of students & .778 & \\
13 & My students follow me as a role model. & .744 & \\
14 & I have moral authority over my students. & .735 & \\
15 & My students come to school, neatly dressed. & .780 & \\
16 & Everything is organized well in my class. & .778 & \\
17 & I do not spare any student for immoral activities.- & .612 & \\
\hline
\end{tabular}

Factor no3: The third factor identified was 'quality of teaching.' The Factorability of the 6 items was examined; the alpha score was .650. The factor loadings were all above 0.5 , which shows a strong relationship between the qualities of teaching.

Table 4

Confirmatory Factor Analysis and Reliability Analyses (Quality of Teaching)

\begin{tabular}{llll}
\hline No. & Statements & $\begin{array}{l}\text { Factor } \\
\text { Loading }\end{array}$ & Alpha \\
& & .732 & .650 \\
18 & I am always well prepared for lessons. & .788 & \\
19 & I always complete the syllabus on time. & .833 & \\
20 & I reflect on my teaching for better results. & .686 & \\
21 & I complete the assigned tasks on time. & .748 & \\
22 & Using fellow teachers to improve my teaching. & .706 & \\
23 & Drive satisfaction from successful improvement. & & \\
\hline
\end{tabular}

Factor no 4: The fourth factor identified was 'motivation.' The Factorability of the 6 items was examined; the alpha score was .698. The factor loadings were all above 0.5 , which shows a strong relationship of motivation.

Table 5

Confirmatory Factor Analysis and Reliability Analyses (Motivation)

\begin{tabular}{clll}
\hline No. & Statements & $\begin{array}{l}\text { Factor } \\
\text { Loading }\end{array}$ & Alpha \\
& & .747 & .698 \\
24 & I challenge myself when teaching. & .758 & \\
26 & Using a review of my performance. & .692 & \\
27 & Individual assessment is important. & .743 & \\
28 & Student's reactions help me judge my teaching. & .752 & \\
29 & Using observations and commit for improvement. & .729 & \\
\hline
\end{tabular}

Factor no 5: The fifth factor identified was 'teamwork.' The Factorability of the 4 items was examined; the alpha score was .602. The factor loadings were all above 0.5 , which shows a strong relationship of teamwork.

\section{Table 6}

Confirmatory Factor Analysis and Reliability Analyses (Teamwork)

\begin{tabular}{clll}
\hline No. & Statements & $\begin{array}{l}\text { Factor } \\
\text { Loading }\end{array}$ & Alpha \\
\hline 30 & Teachers produce work of exceptionally high quality. & .631 & .602 \\
31 & Teachers can contribute to school development. & .766 & \\
32 & Teachers coordinate to achieve curriculum objectives. & .840 & \\
33 & Teachers produce excellent teams of students. & .676 & \\
\hline
\end{tabular}


Factor no 6: The sixth factor identified was 'punctuality.' The Factorability of the 4 items was examined; the alpha score was .698. The factor loadings were all above 0.5 , which shows a strong relationship of teamwork.

Table 7

Confirmatory Factor Analysis and Reliability Analyses (Punctuality)

\begin{tabular}{llll}
\hline No. & \multicolumn{1}{c}{ Statements } & $\begin{array}{l}\text { Factor } \\
\text { Loading }\end{array}$ & Alpha \\
\hline 34 & Teachers come to school regularly and on time. & .813 & .698 \\
35 & Teachers show commitment to their work. & .742 & \\
36 & Teachers begin \& end their classes on time. & .775 & \\
37 & Teachers do not leave any work pending. & .767 & \\
\hline
\end{tabular}

Factor no 7: The seventh factor identified was 'satisfaction with PAS.' Factorability of the 6 items was examined; the alpha score was .723. The factor loadings were all above 0.5 , which shows a strong relationship of satisfaction with PAS.

Table 8

Confirmatory Factor Analysis and Reliability Analyses (Satisfaction with PAS)

\begin{tabular}{llll}
\hline No. & Statements & $\begin{array}{l}\text { Factor } \\
\text { Loading }\end{array}$ & Alpha \\
\hline 38 & I am involved in appraising system. & .729 & .723 \\
39 & It distinguishes poor performers from good ones. & .767 & \\
40 & I would like to be appraised regularly & .734 & \\
41 & The appraisal system is transparent. & .746 & \\
42 & The appraisal is continued throughout the year. & .833 & \\
43 & All teachers are duly informed of their results. & .793 & \\
\hline
\end{tabular}

Factor no 8: The 8th factor identified was 'management support.' The Factorability of the 5 items was examined; the alpha score was .774 . The factor loadings were all above 0.5 , which shows a strong relationship of management support.

\section{Table 9}

Confirmatory Factor Analysis and Reliability Analyses (Management Support)

\begin{tabular}{llll}
\hline No. & Statements & $\begin{array}{l}\text { Factor } \\
\text { Loading }\end{array}$ & Alpha \\
\hline 44 & Our principals guide us during the conduction of PAS. & .790 & .774 \\
45 & Using coordination between teachers and supervisors. & .818 & \\
46 & Using coordination between fellow teachers in PAS. & .725 & \\
47 & Using the appraisal process relates to teacher performance. & .736 & \\
48 & Different student benefits from the appraisal process. & .710 & \\
\hline
\end{tabular}

Factor no 9: The 9th factor identified was 'dissatisfaction with PAS.' Factorability of the 5 items was examined; the alpha score was .862. The factor loadings were all above 0.5 , which shows a strong relationship of dissatisfaction with PAS.

Table 10

Confirmatory Factor Analysis and Reliability Analyses (Dissatisfaction with PAS)

\begin{tabular}{llll}
\hline No. & Statements & $\begin{array}{l}\text { Factor } \\
\text { Loading }\end{array}$ & Alpha \\
\hline 49 & Better training opportunities are not created for teachers. & .744 & .862 \\
50 & PAS has been unable to impact on teacher performance. & .795 & \\
51 & Using management is hardly involved in PAS as a team. & .803 & \\
52 & Appraisal results are never discussed with teachers individually. & .792 & \\
53 & PAS has failed to achieve its objectives. & .713 & \\
\hline
\end{tabular}

Factor no 10: The 10th factor identified was 'need for improvement.' The Factorability of the 4 items was examined; the alpha score was .651. The factor loadings were all above 0.5 , which shows a strong relationship between the need for improvement.

\section{Table 11}

Confirmatory Factor Analysis and Reliability Analyses (Need for Improvement)

\begin{tabular}{clll}
\hline No. & Statements & $\begin{array}{l}\text { Factor } \\
\text { Loading }\end{array}$ & Alpha \\
\hline 54 & There is a need for improvement of present PAS. & .712 & .651 \\
\hline
\end{tabular}




$\begin{array}{lll}55 & \text { The principals and supervisor need thee training to conduct PAS } & .649 \\ 56 & \text { PAS process should be easier and for all teachers. } & .545 \\ 57 & \text { The results of the appraisal should be effectively used for the } \\ & \text { professional development of teachers. }\end{array}$

Ten extractable factors were identified by the scree plot be explaining $71.654 \%$ of the total variance. The data of factors were explored which are theoretically strong as well. It is observed that Cronbach's alpha, a measure of internal consistency was ideally found to be more than 0.75 (Lee \& Wang, 2003) for all subscales. Moreover, all items included had more than 0.3 alpha value with at least one other item of the scale (Fava \& Vellicer, 1996). Kaiser-Meyer Olkin (KMO) was above 0.6 as well, indicating sampling adequacy $\left(\mathrm{KMO}=0.782 \chi^{2}=4058.534, \mathrm{p}<0.000\right)$. These results indicated that the items included in the common factors fit well making exploratory factor analysis worthwhile.

\section{Construct Validation}

The square root of the AVE for all factors was found greater than the absolute value of the correlations with other factors as shown in table 12.

\section{Table 12}

Inter Variable Correlation

\begin{tabular}{|c|c|c|c|c|c|c|c|c|c|}
\hline & F8 & F1 & F2 & F3 & F4 & F5 & F6 & F7 & F9 \\
\hline F8 & 0.77 & & & & & & & & \\
\hline F1 & 0.749 & 0.765 & & & & & & & \\
\hline F2 & -0.277 & & & & & & & & \\
\hline F3 & 0.33 & & -0.263 & & & & & & \\
\hline F4 & -0.467 & -0.093 & 0.593 & -0.488 & & & & & \\
\hline F5 & 0.803 & -0.187 & -0.323 & 0.879 & -0.672 & & & & \\
\hline F6 & -0.826 & -0.501 & -0.162 & -0.247 & -0.142 & -0.55 & & & \\
\hline F7 & -0.648 & -0.254 & 0.36 & -0.177 & 0.374 & 0.234 & -0.901 & & \\
\hline F9 & 0.253 & 0.219 & 0.797 & 0.054 & 0.456 & -0.274 & -0.144 & -0.363 & \\
\hline F10 & -0.793 & 0.083 & 0.642 & -0.746 & 0.862 & & 0.373 & 0.032 & 0.6 \\
\hline
\end{tabular}

The CR values were found higher >.7. The AVE values were found >.5. MaxR $(\mathrm{H})$ values were also observed greater than the values of CR which reflects good construct validity as shown in table 13 .

Table 13

CR, AVE, and MaxR (H) for construct Validation

\begin{tabular}{llll}
\hline & CR & AVE & MaxR(H) \\
\hline F8 & 0.879 & 0.593 & 0.882 \\
F1 & 0.849 & 0.586 & 0.854 \\
F2 & 0.919 & 0.511 & 0.925 \\
F3 & 0.885 & 0.563 & 0.891 \\
F4 & 0.877 & 0.543 & 0.878 \\
F5 & 0.821 & 0.537 & 0.842 \\
F6 & 0.857 & 0.6 & 0.859 \\
F7 & 0.896 & 0.59 & 0.899 \\
F9 & 0.87 & 0.573 & 0.875 \\
F10 & 0.737 & 0.50 & 0.746
\end{tabular}

The construct validity was found a good fit for the model given in the figure below with CFI=.992, RMSEA $<.07$, RMR $<.07, \mathrm{GFI}>.90$ and $\mathrm{p}>.05$. The chi-square goodness of fit test rejected the null hypothesis that the model implied covariance matrix is the same as the empirical covariance matrix for further details sees table 14 . 
Table 14

Model Fit Indices of the Scale

\begin{tabular}{llllllllll}
\hline Model & CMIN & df & $\mathrm{p}$ & $\begin{array}{l}\text { CMIN } \\
\text { /DF }\end{array}$ & RMR & GFI & AGFI & RMSEA & CFI \\
\hline $\begin{array}{l}\text { Model } \\
\text { Fit }\end{array}$ & 9.967 & 3 & .012 & 3.322 & .07 & .906 & .974 & .071 & .992 \\
\hline
\end{tabular}

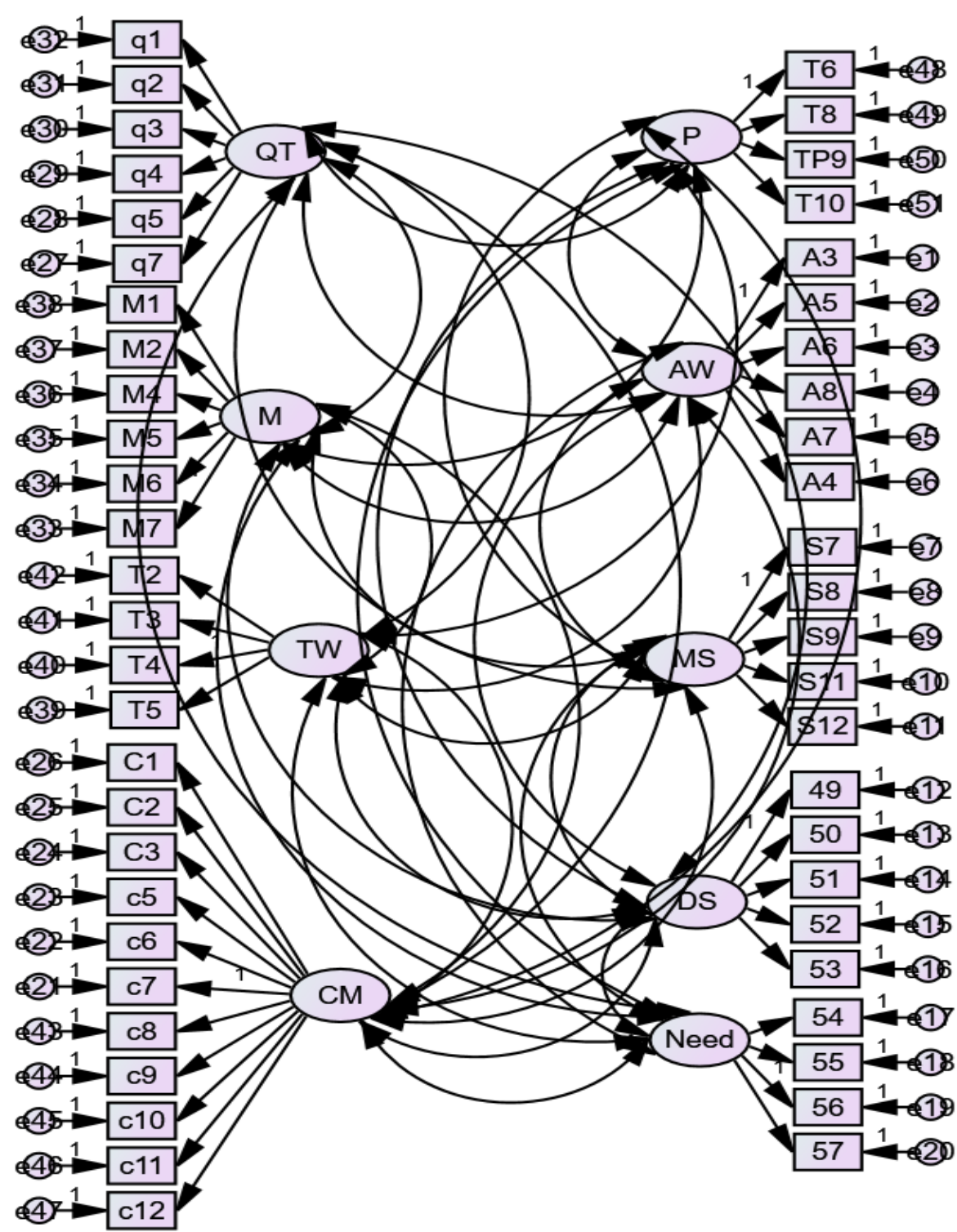

Discussions

Figure2 Confirmatory Factor Analysis

The Appraisal system is a more deliberate method for incorporating Human Resource (HR) activities and evaluating the performance of teachers. PAS is an instrument of Human Resource Management, which affects teachers' promotion decisions for their satisfaction/dissatisfaction with the results (Kleiman, 2000; Edoziem \& Nwideeduh, 2020). The study at hand was conducted by the researcher to develop an instrument for evaluating the Performance Appraisal Scale (PAS-HSSTs) at the higher secondary school level in Punjab (Pakistan). The model was an extension of the previous studies (Farooqi, Akhtar, \& Nadeem, 2013; Nadeem, Farooqi, Shehzad, \& Ahmad, 2014), which included items for awareness of the process, the managerial support during the process, satisfaction and dissatisfaction with the outcomes and need for improvement. It is a pioneer study in the Pakistani public-school context that will help, educators, bureaucrats, and to policymakers use results for further study of the appraisal process. However, the study corroborates many of the previous findings regarding its subscales. It is observed that the appraisal system plays a dynamic role in the employee's 
performance, helping their professional development and motivation (Dessler, 2008; dNisi \& Gonzalez, 2017). Suleman and Gul (2015) stressed the factors concerning classroom management and the effective skills that are relevant to the performance of a teacher. It is identified that the institution's performance criteria should be mentioned and discussed with teachers (Al Shobaki \& Abu Naser, 2016). Feedback influenced teachers' satisfaction towards performance appraisal; researchers (Pichler, Beenen \& Wood, 2018; Leaf and Odhiambo, 2017) supported this idea in his study that managers should be provided in time feedback to teachers for their further improvements. Similarly, the studies (Firestone, 2014; Selvarajan \& Cloninger, 2012) established the relationship between motivation and performance evaluation. PAS-HSSTs have helped in identifying factors that systematically support job satisfaction, highlighting that satisfaction with the evaluation process leads to increased job commitment, while lower degrees of satisfaction leads to lower levels of motivation and burnout (Bakotić, 2016; Brown, Hyatt, \& Benson, 2010).

\section{References}

Ahmad, R., \& Azman N. A. (2004). Performance appraisal decision in Malaysian public service. International Journal of Public Sector Management, 17(1), 48-64.

Al Shobaki, M. J., \& Abu Naser, S. S. (2016). The reality of modern methods applied in the process of performance assessments of employees in the municipalities in Gaza Strip. International Journal of Advanced Scientific Research, 1(7), 14-23.

Akin, S., Yildirim, A., \& Goodwin, A. L. (2016). Classroom management through the eyes of elementary teachers in Turkey: A phenomenological study. Educational Sciences: Theory and Practice, 16(3), 771-797.

Ali, A. Y., Dahie, A. M., \& Ali, A. A. (2016). Teacher motivation and school performance, the mediating effect of job satisfaction: Survey from secondary schools in Mogadishu. International Journal of Education and Social Science, 3(1), 24-38.

Almeida, S., \& Fernando, M. (2017). Cutting: Occupation-specific factors influencing employers in their recruitment and selection of immigrant professionals in the information technology and accounting occupations in regional Australia. International Journal of Human Resource Management, 28(6), 880-912.

Bakotić, D. (2016). Relationship between job satisfaction and organizational performance. Economic Research-Ekonomska Istraživanja, 29(1), 118-130.

Ballou, D., \& Springer, M. G. (2015). Using student test scores to measure teacher performance: Some problems in the design and implementation of evaluation systems. Educational Researcher, 44(2), 77-86.

Bayo-Moriones, A., Galdon-Sanchez, J. E., \& Martinez-de-Morentin, S. (2019). Performance appraisal: dimensions and determinants. The International Journal of Human Resource Management, 1-32.

Brefo-Manuh, A. B., Anlesinya, A., Odoi, A. A. S., \& Owusu, D. R. (2016). Evaluating organizational uses of performance appraisal system: A conceptual analysis and framework for the future. International Journal of Business and Management Review, 4(7), 8-20.

Buckingham, M., \& Goodall, A. (2015). Reinventing performance management. Harvard Business Review, 93(4), 40-50.

Brown, M., Hyatt, D., \& Benson, J. (2010). Consequences of the performance appraisal experience. Personnel Review, 39(3), 375-396

Campatelli, G., Citti, P., \& Meneghin, A. (2011). Development of a simplified approach based on the EFQM model and Six Sigma for the implementation of TQM principles in a university administration. Total Quality Management \& Business Excellence, 22(7), 691-704.

De Moraes, A. (2019). What does it mean to be an effective educator? Analyzing the qualities of a successful and interesting career as an educator in the 21st century. Journal of Applied Learning and Teaching, 2(1), 75-78.

DeNisi, A. S., \& Murphy, K. R. (2017). Performance appraisal and performance management: 100 years of progress? Journal of Applied Psychology, 102(3), 421-433.

DeNisi, A. S., \& Gonzalez, J. A. (2017). Design performance appraisal systems to improve performance. In E, A. Locke (Ed). The Blackwell Handbook of Principles of Organizational Behaviour, 63-75. NY: Wiley

Dessler, G. (2008). Human Resource Management, (11th Ed), London: Prentice-Hall 
Elliott, K. (2015). Teacher Performance Appraisal: More about performance or development? Australian Journal of Teacher Education, 40(9), 102-116.

Edoziem, E. J. \& Nwideeduh, S.B. (2020). Performance management as a correlate of teachers' productivity in Catholic Mission secondary schools in IMO State. Journal of Education in Developing Areas, 27(1), 137-148.

Farooqi, M. T. K., Akhtar, M. M. S., \& Nadeem, M. (2013). Development and Validation of Performance Appraisal Scale (PAS-SSTs) for Secondary School Teachers. J. Asian Dev. Studies, 2(4), 88-97.

Fava, J. L., \& Velicer, W. F. (1996). The effects of under extraction in factor and component analysis. Educational and Psychological Measurement, 56, 907 - 929.

Finster, M., \& Milanowski, A. (2018). Teacher perceptions of a new performance evaluation system and their influence on practice: A within-and between-school level analysis. Education Policy Analysis Archives, 26, 41-55.

Firestone, W. A. (2014). Teacher evaluation policy and conflicting theories of motivation. Educational Researcher, 43(2), 100-107.

Fish, M. C., Gefen, D. R., \& Kaczetow, W., Winograd, G. \& Futtersak-Goldberg, R. (2016). Development and validation of the college campus environment scale (cces): promoting positive college experiences. Innovation in Higher Education, 41, 153-165

Gelder, T. V. (2005). Teaching critical thinking: Some lessons from cognitive science. College Teaching, 53(1), 41-48.

Hamilton, L. S., Schwartz, H. L., Stecher, B. M., \& Steele, J. L. (2013). Improving accountability through expanded measures of performance. Journal of Educational Administration, 51(4), 453-475.

Howard, B. B., \& McColskey, W. H. (2001). Evaluating experienced teachers. Educational Leadership, 58(5), 48-51.

Hu, L., \& Bentler, P. M. (1999). Cut-off criteria for fit indexes in covariance structure analysis: Conventional criteria versus new alternatives. Structural Equation Modeling, 6, 1-55

Iqbal, K. (2013). Determinants of organizational justice and its impact on job satisfaction. A Pakistan based survey. International Review of Management and Business Research, 2(1), 48-56.

Kanto, K., Ahmad, M. A., Talib, S. B., \& Tiro, M. A. (2014). The influence of certification toward work motivation, job satisfaction, and performance of state high school guidance and counseling teacher in South Sulawesi. International Journal of Science and Technology Research, 3(8), 386-394.

Kaiser, H. F. (1974). An index of factorial simplicity. Psychometrika, 39(1), 31-36.

Kleiman, L. S. (2000). Human resource management: A tool for competitive advantage. Cincinnati: South-Western college publishing.

Kwok, A. (2017). Relationships between instructional quality and classroom management for beginning urban teachers. Educational Researcher, 46(7), 355-365.

Leaf, A., \& Odhiambo, G. (2017). The deputy principal instructional leadership role and professional learning: Perceptions of secondary principals, deputies, and teachers. Journal of Educational Administration, 55(1), 33-48.

Lee, E. T., \& Wang, J. (2003). Statistical methods for survival data analysis (Vol. 476). John Wiley \& Sons, New York.

Marx, G. (2007). Research Brief-Teacher Evaluation. Education Partnerships, ERIC, Eastern Michigan University Michigan. Retrieved August 8, 2009.

Mayer, D. (2014). Forty years of teacher education in Australia: 1974-2014. Journal of Education for Teaching, 40(5), 461-473.

McKim, C. A. (2017). The value of mixed methods research: A mixed-method study. Journal of Mixed Methods Research, 11(2), 202-222.

McKnight, P. E., McKnight, K. M., Sidani, S., \& Figueredo, A. J. (2007). Missing data: A gentle introduction. New York, NY: Guilford Press.

Nadeem, M., Farooqi, M. T. K., Shehzad, M. N., \& Ahmad, M. (2014). Performance appraisal system: A gender-based comparison of secondary school teachers in Pakistan. Practice, 8, 921. 
Nadeem, M., Arif, S. \& Asghar, Z. (2019). Effectiveness of the teacher appraisal system in public higher secondary schools of Punjab (Pakistan). Global Regional Review, 4(1), 194- 208.

Nadeem, M., Arif, S., \& Naeem, M. (2020). The Role of Principals and Administrators in Performance Appraisal of School Teachers in Punjab. Sir-Syed Journal of Education and Social Sciences, 3(2), 132-142.

Perlaza, A. M., \& Tardif, M. (2016). Pan-Canadian Perspectives on Teacher Education: The State of the Art in Comparative Research. Alberta Journal of Educational Research, 62(2), 199-219.

Peterson, K. (2004). Research on schoolteacher evaluation. Nassp Bulletin, 88(639), 60-79.

Pichler, S., Beenen, G., \& Wood, S. (2018). Feedback frequency and appraisal reactions: a metaanalytic test of moderators. The International Journal of Human Resource Management, 126.

Reddy, L. A., Dudek, C. M., Peters, S., Alperin, A., Kettler, R. J., \& Kurz, A. (2018). Teachers' and school administrators' attitudes and beliefs of teacher evaluation: a preliminary investigation of high poverty school districts. Educational Assessment, Evaluation, and Accountability, 30(1), 47-70.

Ronfeldt, M., Farmer, S. O., McQueen, K., \& Grissom, J. A. (2015). Teacher collaboration in instructional teams and student achievement. American Educational Research Journal, 52(3), 475-514.

Selvarajan, T. T., \& Cloninger, P. A. (2012). Can performance appraisals motivate employees to improve performance? A Mexican study. The International Journal of Human Resource Management, 23(15), 3063-3084.

Simmons, J. (2003). Balancing performance, accountability, and equity in stakeholder relationships: towards more socially responsible HR practice. Corporate Social Responsibility and Environmental Management, 10(3), 129-140.

Stufflebeam, D. L. (2003). The CIPP model for evaluation. International Handbook of Educational Evaluation (pp. 31-62). Springer, Dordrecht.

Suleman, Q. \& Gul, R. (2015), Challenges to successful total quality management implementation in public secondary schools: A case study of Kohat District, Pakistan, Journal of Education and Practice, 6(15), 23-134.

Taut, S., \& Sun, Y. (2014). The development and implementation of a national, standards-based, multi-method teacher performance assessment system in Chile. Education Policy Analysis Archives, 22, 71-82.

Tong, Y. K., \& Arvey, R. D. (2015). Managing complexity via the competing values framework. Journal of Management Development, 34(6), 653-673.

Warokka, A., Gallato, C. G., Thamendren, A., \& Moorthy, L. (2012). Organizational justice in the performance appraisal system and work performance: evidence from an emerging market. Journal of Human Resources Management Research, 2012, 1. 